\section{Beztsennyi I., Bondzyk D., Dunayevska $\mathbf{N}$., Nekhamin M.}

\title{
RESEARCH OF CO-COMBUSTION OF SOLID BIOFUEL WITH LEAN AND BITUMINOUS COAL
}

Об'єктом дослідження є процеси термічного перетворення енергетичного вугілля та біомаси, з метою створення високоефективних екологічно чистих технологій його спільного спалювання в паливні котлоагрегатів.

Однією з важливих проблем, яка гальмує впровадження спільного спалювання біомаси з вугіллям, є недостатня вивченість взаємодії двох дуже різних твердих палив. Недослідженими залишаються характеристики розмелювання, аеродинаміка частинок, кінетика всіх стадій горіння під час спільного спалювання двох твердих палив. Спільне спалювання біомаси з вугіллям дозволяє частково замістити дефіцитні марки енергетичного вугілля, а також зменшити викиди шкідливих газів та пилу.

Для вивчення особливостей спільного спалювання вугілля та біомаси використовувались експериментальні та розрахункові методи дослідження, в тому числі спалювання на потоковій установці, яка призначена для вивчення характеристик горіння пилоподібних палив.

Експерименти по спільному спалюванню пісного та газового вугілля із різними видами твердої біомаси показали покращення умов займання вугілля, із додаванням біомаси від 5 до 15 \% за теплом. Показано вплив домішки біомаси до вугілля на розподіл температур по довжині факела. В роботі наведені залежності ступеня конверсї̈ газового вугілля та його сумішей з подрібненими пелетами сосни, соломи пшениці та лушпинням соняшника, а також пояснена природа иієї залежності. За газовим аналізом продуктів згоряння показаний вплив домішування біомаси до газового вугілля на утворення оксидів азоту.

Отримані висновки та залежності обгрунтовують екологічну доцільність та ефективність спільного спалювання і дозволяють перейти до розробки пілотного проекту часткового заміщення вугілля на різні види твердого біопалива.

Ключові слова: теплові електростанщї, пиловугільне спалювання, енергетичне вугілля, тверда біомаса, спільне спалювання.

Received date: 24.09 .2019

Accepted date: 21.10 .2019

Published date: 30.12 .2019
Copyright (C) 2019, Beztsennyi I., Bondzyk D., Dunayerska N., Nekhamin M. This is an open access article under the CC BY license (http://creativecommons.org/licenses/by/4.0)

\section{Introduction}

Through the military-political situation that has developed in Ukraine recently, an acute shortage of anthracite and lean coal has arisen. For almost half of Ukrainian pulverized coal thermal power plants (TPPs), these coal grades are project fuels.

It is possible to partially compensate for the indicated fuel shortage by co-combustion of coal with solid biomass. Today, Ukraine has significant potential in the production of biofuels, namely wood and agricultural. According to the bioenergy association of Ukraine, the annual biomass potential in Ukraine is estimated at 30 million tons of standard fuel (s.f.) - $23 \%$ of the primary energy consumption in the country, which makes it possible to consider solid biomass as an alternative fuel.

To assess the optimal ratios of coal and biomass, given the significant differences in the elemental composition, structure and reactivity, it is necessary to study the processes of the mutual influence of two solid fuels during joint combustion.

Therefore, it is relevant to study the characteristics of the combined combustion of lean and bituminous coal with various most common types of solid biomass.

\section{The object of research and its technological audit}

The object of research is the processes of thermal conversion of steam coal and biomass, with the aim of creating effective and environmentally friendly technologies for its joint combustion.

Co-combustion of coal with biomass can be organized in a dense layer, a fluidized bed and using flare technology. In this work, let's consider the results of studies of the peculiarities of co-combustion of biomass with coal precisely with the flare method due to the lack of layered boilers in large energy (except for one boiler at Starobeshevska TPP (Novyi Svit, Ukraine), which is located on a temporarily occupied territory).

Until 2013, anthracite coal-dust TPPs of Ukraine consumed about 18 million tons of coal products per year, and already in 2015, the revenues of domestic anthracite and lean coal at TPPs decreased to less than 6.8 million tons. As a result, compared with 2013, electricity production at thermal power plants decreased by $44 \%$, which is insufficient to regulate the energy consumption schedule and poses a direct threat to Ukraine's energy independence. In recent years, there has been a gradual 
transfer of anthracite blocks to the combustion of coal of a bituminous group [1-3], which requires a significant amount of time and financial resources. The conversion of all anthracite boiler units of domestic TPPs and cogeneration plants (CP) to combustion bituminous coal may, under certain conditions, lead to its deficit. This factor, along with the goal of replacing fossil fuels with renewable sources, has become the reason for studying the features of co-combustion not only anthracite, but also bituminous coal with biomass.

Along with the problem of finding alternative fuels for anthracite thermal power plants in the Ukrainian energy sector, there is a need to increase the production of heat and electricity from renewable energy sources. Within the framework of the European Energy Community, Ukraine should reduce emissions of harmful substances and greenhouse gases from large-scale combustion plants. Since the biomass is $\mathrm{CO}_{2}$ neutral and almost does not contain sulfur and ash, it is an ideal fuel for energy without pollution $[4,5]$.

\section{The aim and objectives of research}

The aim of research is investigation of the features of co-combustion of coal of brands L (lean) and B (bituminous) with solid biomass in the form of crushed pellets in order to determine the optimal ratio of the two types of fuel.

To achieve this aim, it is necessary to complete the following tasks:

1. Assess the experience of co-combustion of coal and biofuels in the world.

2. Determine the dependences of temperature changes and the position of the torch core during co-combustion of coal with various types of biomass.

3. Obtain the dependences of the burn-up completeness of a blend of various types of biomass with bituminous coal on the ratio of two fuels.

4. Assess changes in the characteristics and emissions of combustion plants during the implementation of cocombustion of biomass with coal.

\section{Research of existing solutions of the problem}

Co-combustion at large power plants is the most economical option to use the biomass energy potential for the production of electricity and heat, due to the higher efficiency of blocks compared to low-power boilers. In addition, the technology of specifically flaring biomass and coal in powerful energy steam generators allows to get the highest efficiency compared to others. Currently, 230 TPPs and TPPs with capacities from 50 to $700 \mathrm{MW}$ use cocombustion. This technology is popular mainly in Asian countries (Japan, China), the USA and the EU. In the EU today, more than 100 power plants using co-combustion are in operation. As of the end of 2019, there are 19 large pulverized coal plants in the UK that used co-combustion of coal with biomass [6]. The UK government has taken the direction of energy development, in which there will be no place for coal, and some coal stations are completely converted to biomass combustion. For example, if in the balance of electricity generation in 2012 coal amounted to about $40 \%$, then in 2017 its share decreased to $2 \%$.

Foreign experience of long-term co-combustion of biomass with coal has proved that this technology has undeniable positive health effects on the environment. Biomass contains almost no sulfur and fuel nitrogen, so its addition to coal leads to a reduction in $\mathrm{SO}_{2}$ and $\mathrm{NO}_{2}$ emissions per unit of energy produced. Joint combustion of biomass at power plants solves another environmental problem - the disposal of agricultural waste and the woodworking industry [7, 8].

The proliferation of technologies for co-combustion of biomass and coal has created a market for energy biomass and an appropriate transport and procurement infrastructure, which has created a significant number of jobs. Strengthening emissions requirements for coal-fired power plants in the EU countries, most electricity producers intend to disseminate the practice of using biofuels in large energy [9].

The spread of co-combustion practices is also facilitated by the lack of the need for large investments and the possibility of using the existing infrastructure and equipment of power plants. Co-combustion technology allows to quickly change the ratio of biomass and coal, which allows power plants to diversify fuel supplies [10].

Along with the benefits of co-combustion, there are factors that inhibit the overall spread of this technology. One of the drawbacks is the presence in some types of biomass of potassium, sodium, and chlorine, which can lead to acceleration of corrosion of heating surfaces or their slagging [11, 12]. Another disadvantage of the technology is the not always stable supply of biofuels with the required characteristics to the power plant due to the seasonality factor, a wide range of biomass properties of one species, etc. [13].

The technology of co-combustion of biomass and coal is divided into direct, parallel and indirect combustion [14]. During direct combustion, biomass and coal are fed simultaneously to the furnace. In this case, options are possible when the biomass is blended with coal directly in the fuel depot, co-milled and simultaneously fed to combined burner devices. There are modifications of this technology, according to which biomass is preliminarily prepared on separate crushing devices and fed to combined burners (Studstrup, Denmark, coal - straw), or biomass is fed to specially selected burners. In parallel with the existing coal-dust steam generator, a dedicated steam generator is attached to burn the crushed biomass in a torch. Indirect combustion of biomass and coal involves the preliminary processing of biomass in the furnaces or in the gasifier, and the resulting pyrolysis gas or gasification products are burned together with coal in the furnaces of existing steam generators.

Direct combustion is the most common co-combustion method in the world and is the most acceptable co-combustion method for coal-dust boiler units of Ukrainian thermal power plants. During direct co-combustion, particles of both solid fuels burn in the same volume, which causes their interaction [15]. Therefore, for energy-efficient and ecological implementation of this technology, it is necessary to study the characteristics of combustion blends of solid biofuel with coal. This paper presents the results of experimental flare co-combustion of three types of biomass with lean and bituminous coal.

\section{Methods of research}

Co-combustion of coal and biomass under conditions similar to those in fuel boilers was carried out at the Coal Energy Technology Institute of National Academy of Sciences of Ukraine at the VGP-100V experimental unit (Ukraine), which allows the combustion of two solid 
fuels simultaneously with a flow rate of up to $30 \mathrm{~kg} / \mathrm{h}$. The temperature level can be up to $1700{ }^{\circ} \mathrm{C}$, while the flow rates of the components, the temperature along the length and the composition of the gases at the outlet of the installation are controlled.

A schematic diagram of VGP-100V pilot unit at thermal power in the regime of combustion coal in raw air up to $100 \mathrm{~kW}$ [16] is shown in Fig. 1. The total length of the reactor $4.8 \mathrm{~m}$, the section of the reactor before turning into a cyclone of $3.2 \mathrm{~m}$; the length of the diagnostic section from the original section of the burner is $2.4 \mathrm{~m}$.

The diagnostic section consists of 4 sections $0.6 \mathrm{~m}$ long, $0.28 \mathrm{~m}$ inner diameter. The water-cooled walls of the reactor are internally coated with a three-layer lining. The sections provide for operational diagnostic holes used to introduce thermocouples, gas-assisted probes, and pyrometric measurements.

The burner device is a vertical water-cooled lined cylinder with an inner diameter of $0.2 \mathrm{~m}$, length $0.5 \mathrm{~m}$, installed through a water-cooled adapter flange on the upper cut of the reactor, equipped with two burners and operational diagnostic windows. At its end, the main gas burner is installed, designed to burn natural gas. In addition to air and natural gas, coal dust is supplied to it from the feeder. Coaxially located natural gas channel, which ends with a short section with perforation for gas exit. Coaxial gas is the channel for supplying air or a mixture of air and coal, which ends with a blade swirl to intensify the mixing of air with gas, and coal - with the products of gas combustion.

The installation provides for the supply of natural gas, air (to the main and auxiliary burners transporting air with coal and biomass, secondary air), biomass and coal dust.

In the experiments, the flow rates of natural gas, air, biomass, coal dust, the length of the lining, the temperature of the gas stream, the vacuum in the reaction zone, and the composition of the combustion products at the outlet of the reactor are controlled.

The gas phase for analysis is taken continuously at the outlet of the reactor with a water-cooled sampling probe equipped with a filter - a solid phase collector at the outlet.

At a flow temperature of $1200-1250{ }^{\circ} \mathrm{C}$, the residence time of the fuel particles was $0.75-0.8 \mathrm{~s}$, which is close to the residence time of the particles in the lower radiation part of the pulverized coal boilers. Previous studies [17] indicate that during this time when high-ash anthracite dust is burned, the degree of carbon conversion is reached $X_{c}=0.6-0.8$, which also corresponds to the characteristics of coal-dust boilers [18].

A study on co-combustion of biomass and coal is carried out in two stages of experiments. At the first stage, lean coal is burned with pine pellets, agro-pellets and pellets of sunflower stalks, in the second - bituminous coal with pine pellets of the second batch, wheat straw and sunflower husks. Each stage consists of several experimental series, during which coal is burned with each type of biomass in 2-3 proportions. First, the regime parameters of stable combustion of coal dust were determined, and then a certain fraction of biomass is added. Analysis of the technical characteristics of the studied fuels is given in Table 1.

For combustion, coal dust of a standard station grinding is selected. Sieving details of biomass pellets are given in Table 2.

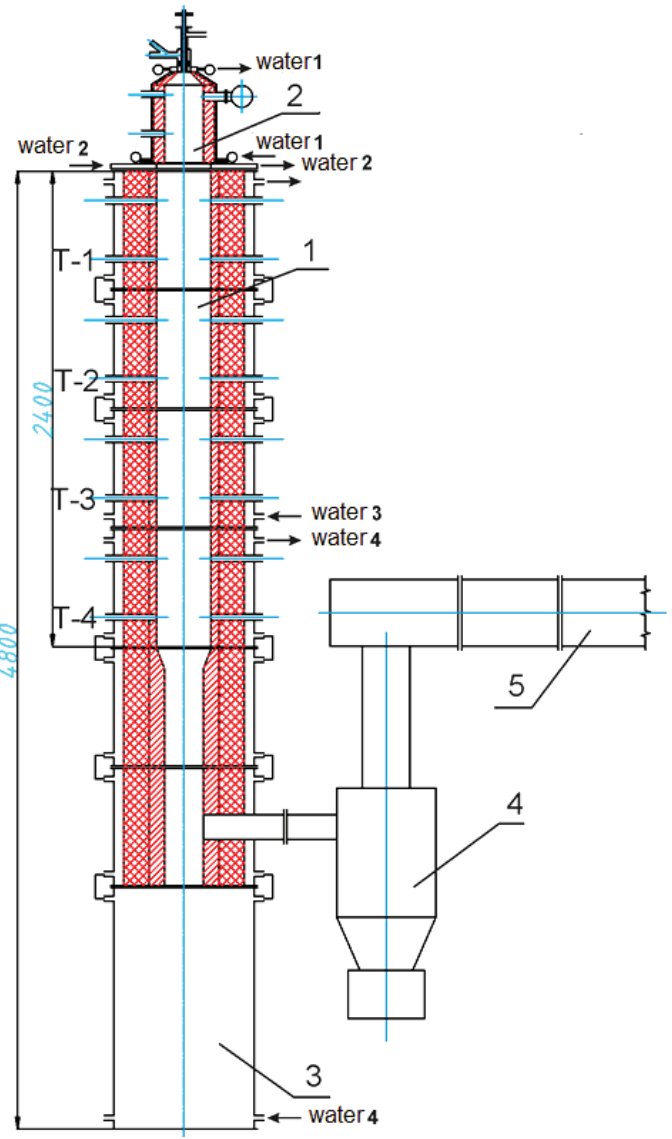

Fig. 1. VGP-100V experimental unit: 1 - diagnostic section of the reactor 2 - burner device; 3 - slag collect; 4 - cyclone; 5 - afterburner and cooling chamber

Table 1

Technical and elemental analysis of test fuels

\begin{tabular}{|c|c|c|c|c|c|c|c|c|c|c|c|c|}
\hline \multirow[b]{2}{*}{ Sample name } & \multirow{2}{*}{$\begin{array}{l}\text { Total moisture } \\
\text { on the working } \\
\text { condition of the } \\
\text { fuel, } W_{t}^{T}, \%\end{array}$} & \multirow{2}{*}{$\begin{array}{c}\text { Dry ash } \\
\text { content } \\
\text { of fuel, } \\
A^{d}, \%\end{array}$} & \multirow{2}{*}{$\begin{array}{c}\text { Dry sulfur } \\
\text { total fuel, } \\
S_{t}^{d}, \%\end{array}$} & \multirow{2}{*}{$\begin{array}{c}\text { The } \\
\text { yield of } \\
\text { volatiles, } \\
V^{\text {daf }} \%\end{array}$} & \multicolumn{2}{|c|}{ Calorific value } & \multirow{2}{*}{$\begin{array}{c}\text { Chlorine } \\
\text { content, } \\
\mathrm{Cl}^{d}, \%\end{array}$} & \multicolumn{5}{|c|}{ Element composition, \% } \\
\hline & & & & & $\begin{array}{c}\text { Higher, } \\
\square_{s}^{\text {daf }}, \mathrm{MJ} / \mathrm{kg}\end{array}$ & $\begin{array}{c}\text { Lower, } \\
\square_{i}^{r}, \mathrm{MJ} / \mathrm{kg}\end{array}$ & & $\complement^{\text {daf }}$ & $\mathrm{H}^{d a f}$ & $0^{\text {daf }}$ & $\mathrm{N}^{\text {daf }}$ & $5^{d a f}$ \\
\hline Pine pellets 1 & 8.7 & 0.4 & 0.03 & 85.9 & 20.921 & 17.632 & 0.04 & 51.87 & 6.33 & 41.63 & 0.14 & 0.03 \\
\hline Agro-pellets & 8.4 & 6.1 & 0.14 & 82.0 & 19.629 & 15.573 & 0.27 & 50.30 & 6.21 & 42.81 & 0.53 & 0.15 \\
\hline Sunflower stalks pellets & 9.3 & 9.7 & 0.18 & 80.3 & 19.647 & 14.814 & 0.42 & 49.35 & 6.20 & 43.35 & 0.89 & 0.21 \\
\hline Lean coals & 6.0 & 19.0 & - & 14.7 & - & 25.5 & - & - & - & - & - & 0.84 \\
\hline Wheat pellets & 9.0 & 12.4 & 0.12 & 84.2 & 19.667 & 14.410 & 0.39 & 49.6 & 6.55 & 41.56 & 2.15 & 0.14 \\
\hline Pine pellets 2 & 6.8 & 0.8 & - & 86.1 & 21.092 & 18.077 & 0.10 & 52.93 & 6.64 & 37.67 & 2.76 & - \\
\hline Sunflower husk pellets & 10.7 & 5.8 & 0.24 & 80.7 & 21.786 & 16.972 & 0.53 & 53.77 & 6.38 & 38.10 & 1.49 & 0.26 \\
\hline Bituminous coal & 1.3 & 23.5 & 2.44 & 43.1 & 35.388 & 21.47 & 0.61 & 86.99 & 5.00 & 5.31 & 1.44 & 1.26 \\
\hline
\end{tabular}


Sieving prepared for combustion biomass

\begin{tabular}{|c|c|c|c|c|c|c|}
\hline Fraction, mm & Pine pellets 1, \% & Agra-pellets, \% & Sunflower stalks pellets, \% & Wheat pellets, \% & Pine pellets 2, \% & Sunflower husk pellets, \% \\
\hline$>3$ & 19.30 & 23.67 & 27.70 & 0.00 & 0.00 & 0.00 \\
\hline $1.6-3$ & 32.50 & 28.52 & 26.66 & 0.34 & 0.40 & 0.27 \\
\hline $1-1.6$ & 20.29 & 19.62 & 18.98 & 10.38 & 14.58 & 9.84 \\
\hline $0.63-1$ & 10.64 & 10.31 & 9.60 & 18.15 & 21.29 & 20.68 \\
\hline $0.4-0.63$ & 8.50 & 7.92 & 7.41 & 22.69 & 24.75 & 28.79 \\
\hline $0.2-0.4$ & 6.12 & 6.18 & 6.24 & 25.05 & 23.08 & 24.09 \\
\hline $0.09-0.2$ & 2.10 & 2.94 & 2.77 & 15.35 & 10.67 & 12.73 \\
\hline$<0.09$ & 0.54 & 0.83 & 0.66 & 8.02 & 5.22 & 3.59 \\
\hline
\end{tabular}

As can be seen from the Table 2, the average biomass size does not differ significantly in each of the stages of the experiments.

\section{Research results}

At the first stage, lean coal is burned with pine pellets of the first batch, agro-pellets and pellets of sunflower stalks in various proportions (the percentage of biomass in heat is indicated in percent).

The main indicators of the burn-up rate of the experimental regimes are flow temperatures $T$, ${ }^{\circ} \mathrm{C}$. After combustion lean coal while feeding biomass to the reactor, the temperatures in sections 2 and 3 almost always increased by $100-200{ }^{\circ} \mathrm{C}$, while the heat of combustion of the biomass is lower. This is explained by the greater reactivity of biomass, which allows to reduce the torch and, accordingly, to reduce the burn-up time of the fuel. Temperature profiles along the length of the reactor depending on the fraction of biomass are shown in Fig. 2. For each type of biomass, temperature profiles obtained in each series of experiments.

When the smallest fraction of pine pellets (6.5\%) is added to lean coal, a slight temperature increase of about $30^{\circ} \mathrm{C}$ is observed and the torch core shifted $0.5 \mathrm{~m}$ downward further from the burner (Fig. 2, $a$ ). With an increase in the proportion of pine pellets at $12.7-14.5 \%$ in heat, the increase in the temperature of the torch amounted to 80-120 ${ }^{\circ} \mathrm{C}$ (Fig. 2, b); the core has a slight shift towards the outlet of the installation.

A study of co-combustion of lean coal dust and agropellets shows a lesser effect of biomass combustion (which has a lower calorific value than pine pellets). The share of agro-pellets in the third series of experiments ranges from 7.7 to $12.0 \%$. In this case, the maximum temperature increase $\left(140{ }^{\circ} \mathrm{C}\right)$ is noted at a consumption of agro-pellets of $9.6 \%$ by heat (Fig. 2, c).

Combined combustion of ground pellets of sunflower straw with coal ensured an increase in the temperature of the flare core from $100-140{ }^{\circ} \mathrm{C}$ with a yield of $8.5-11.7 \%$ biomass (Fig. 2, d). In this case, the torch core moves closer to the burner, which indicates an intensification of the ignition and combustion process.

The experiments of the first stage show that even with fluctuations in the calorific value of biomass from 14.8 to 17.6 $\mathrm{MJ} / \mathrm{kg}$, fluctuations in the temperature of the torch core turns out to be insignificant $-50-70{ }^{\circ} \mathrm{C}$. At the same time, agro-pellets from straw, which have not the highest heat of combustion.
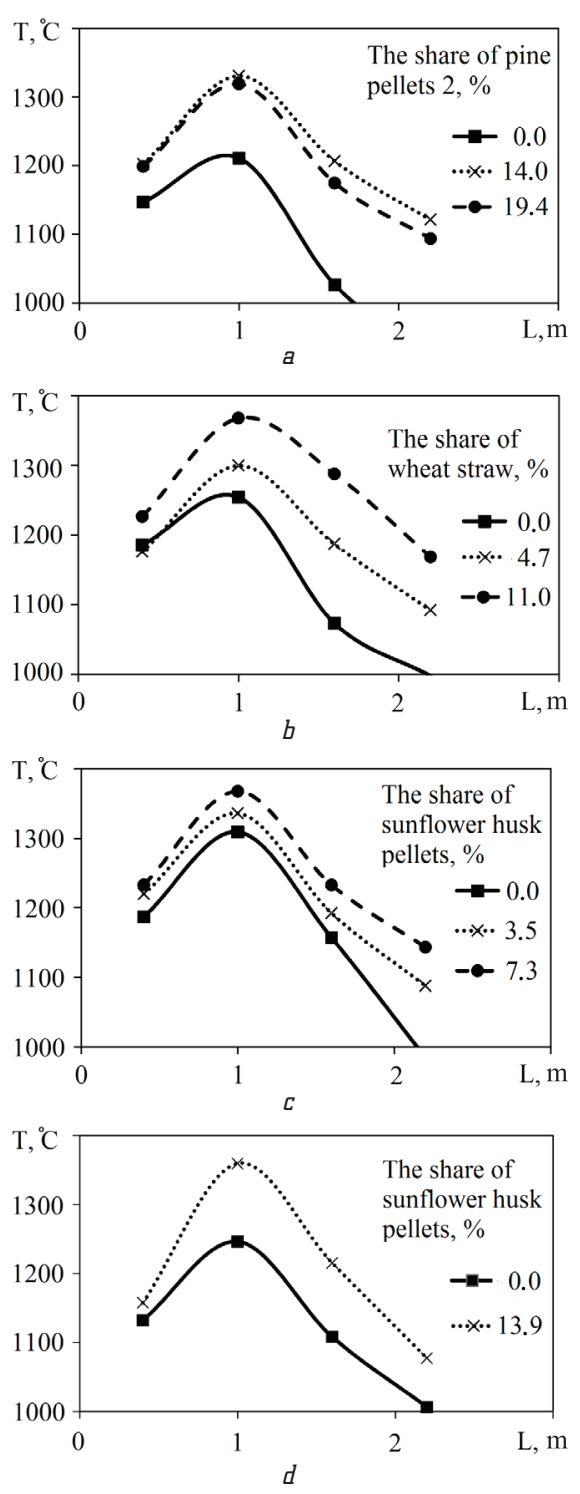

Fig. 2. The temperature in the reactor in the modes of co-combustion of dust of lean coal and crushed pellets: $a$ - pine 1 of the first series; $b$ - pine 1 of the second series; $c$ - agricultural crops; $d$ - sunflower stalks

At the second stage, bituminous coal is burned with pine pellets of the second batch, wheat straw and sunflower husks in different proportions. Thermocouples are installed in the same places as in the first stage. Bituminous coal contains more than $40 \%$ volatile substances and has a much 
greater reactivity compared to lean coal, which ensures its stable combustion without the use of gas. However, the addition of biomass, has a lower calorific value per bituminous coal, leads to an increase in temperature in the reactor by $100-200{ }^{\circ} \mathrm{C}$, which indicates the intensification of ignition of even highly reactive coal. Temperature profiles along the length of the reactor depending on the fraction of biomass are shown in Fig. 3.
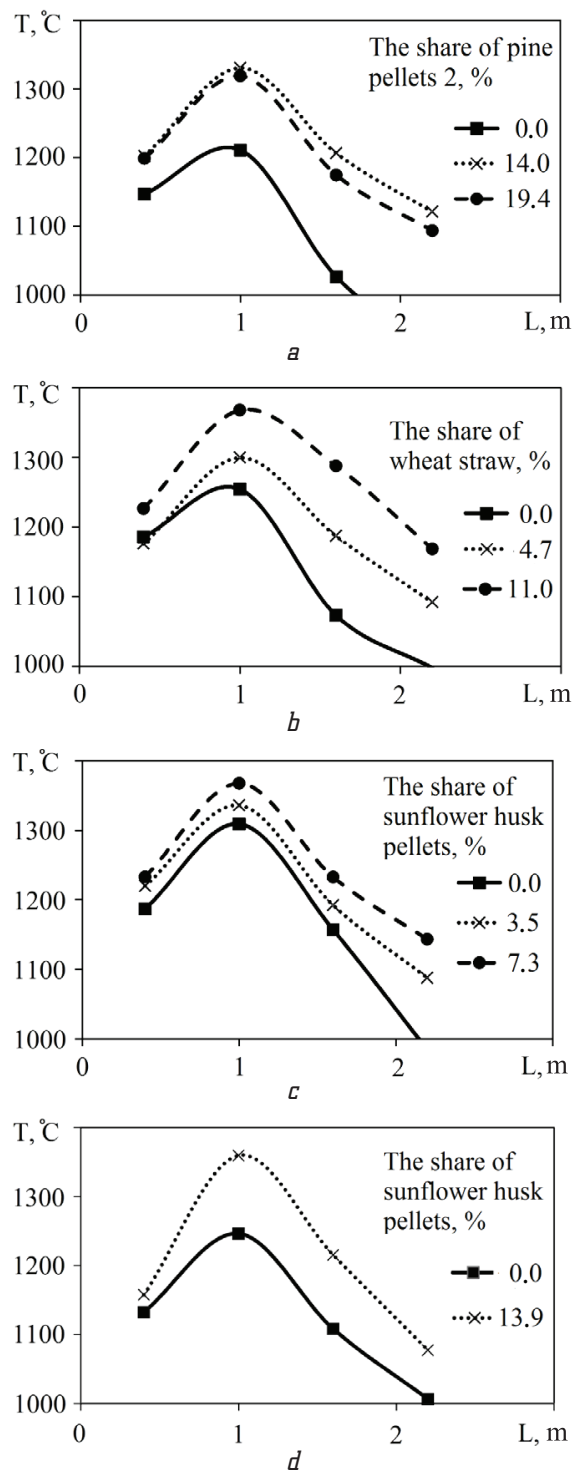

Fig. 3. The temperature in the reactor in the modes of co-combustion of bituminous coal dust and crushed pellets: $a$ - pine 2; $b$ - wheat straw; $c$ - sunflower husk of the third series; $d$ - sunflower husk of the fourth series

After the regime on bituminous coal, a certain proportion of crushed pine pellets of the second batch, which has the highest calorific value from the studied biomass samples, is supplied to the inlet. The response of the unit to the addition of biomass is almost the same - there is a rise in temperature of $120^{\circ} \mathrm{C}$ in the 2nd section and a slightly larger rise in other sections (Fig. 3, $a$ ). The maximum temperature is observed in the range of the share of biomass by heat value from $7-8 \%$ to $14-15 \%$.

In the second stage of research, in contrast to the first, the degree of burnout of the fuel as a whole is controlled.
This important indicator of the combustion process is necessary to determine the optimal proportion of biomass in the blend with coal. It is not possible to separate separately the degree of burnout of biomass and coal, although with different reactivity, the burn-up rate of coal and biomass is different. Therefore, the degree of fuel burnout characterized the combustion process as a whole. For this purpose, the combustion products are smoothed out by a probe at the outlet of the installation, from which solid particles are filtered. Using the ash content of the sample, the average conversion degree for two fuels is calculated. The dependences of the conversion degree of blends on the biomass content of the blend with bituminous coal are shown in Fig. 4.

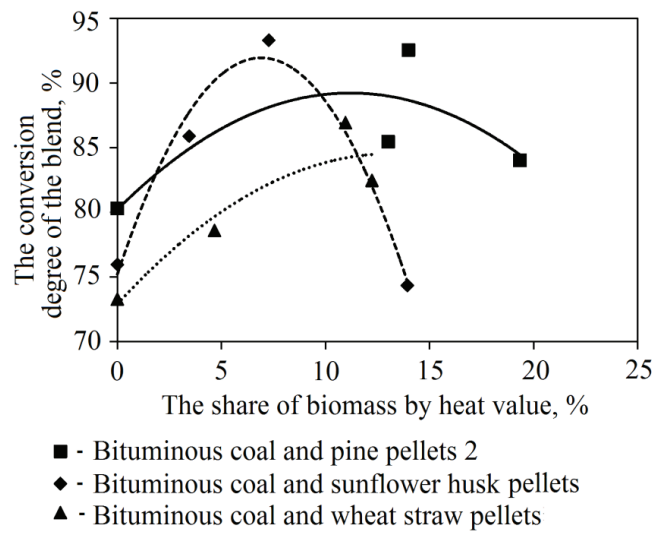

Fig. 4. The conversion degree of a blend of bituminous coal and various types of biomass depending on the proportion of biomass in the blend

Calculations of the conversion degree demonstrate an improvement in the completeness of the burnout of the blend by adding the smallest fraction of biomass (about $5 \%$ ). With an increase in the share of biomass in the burnout blend, it improved even more and reached a maximum value in the range of $8-14 \%$. The presence of an extremum can be explained by a change in the balance of multidirectional effects. On the one hand, adding in a small amount of more highly reactive fuel, which is faster than coal, improves the ignition conditions of the latter. In this case, oxygen is consumed for combustion of additional volatile biomass substances, which occurs at the root of the torch, which leads to a decrease in the concentration of the oxidizing agent in its core. With the addition of only $5 \%$ biomass, this slight decrease does not slow the combustion of coal particles. With an increase in the biomass fraction of more than 8-14\%, the effect of oxygen deficiency begins to prevail over the positive effect of early ignition of coal, which leads to a decrease in the conversion degree of the blend relative to the maximum value. Also, a decrease in the positive effect with the addition of biomass of more than $8-14 \%$ is affected by a decrease in the calorific value of the blend. For a significantly lower calorific value of biomass, its further addition does not lead to an increase in temperature in the torch core (Fig. 3).

An increase in core temperature should lead to an increase in emissions of thermal nitrogen oxides, and low nitrogen content in biomass should reduce emissions of 
fuel nitrogen oxides from co-combustion. Evaluation of the resulting effect of adding biomass to the formation of $\mathrm{NO}$ is carried out using gas analysis. The concentration of nitric oxide at the outlet of the installation, depending on the fraction of biomass, is shown in Fig. 5.

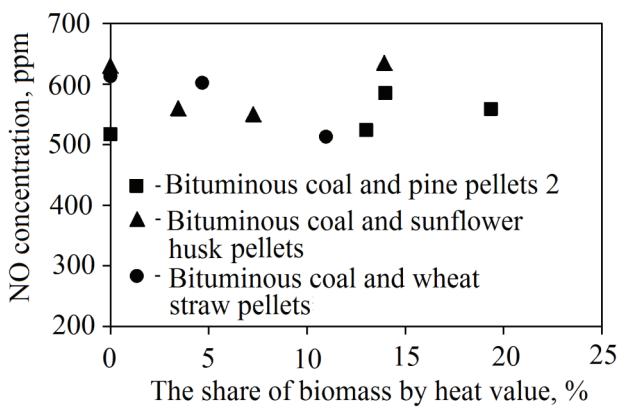

Fig. 5. The concentration of nitric oxide at the output depending on the biomass proportion

Gas analysis shows that with an increase in the proportion of biomass for all three types of biomass, there is no change in the average level of nitric oxide concentrations. Therefore, an increase in the formation of thermal oxides is offset by a decrease in thermal oxides of nitrogen. This suggests that in fuel boilers, where the temperature level during co-combustion significantly differs from the regimes of coal combustion, a slight decrease in the formation of nitrogen oxides can be expected.

\section{SWOT analysis of research resutls}

Strengths. Co-combustion of coal with biomass allows to diversify the fuel supply of Ukrainian coal TPPs and TPPs, reduce emissions of dust, sulfur and nitrogen oxides, reduce the charge for carbon dioxide emissions, and also improve the completeness of coal combustion. The use of domestic biofuels in large power plants will accelerate the creation of a biofuel market in Ukraine and create an additional source for economic growth. The introduction of direct co-combustion does not require large investments and allows to maximize the use of existing equipment.

Weaknesses. The disadvantages of co-combustion include the lack of common biofuel quality standards in Ukraine, in particular, the biomass is not analyzed for the content of chlorine and potassium, as well as the melting temperature of ash. There is currently no biomass market. A detailed logistics system for the supply of biomass to large power plants is not developed. Seasonality of biomass. Currently, the cost of heat generated from biomass is higher than coal.

Opportunities. The introduction of co-combustion in coal-fired power plants can reduce the cost of emissions of dust, carbon dioxide, sulfur oxides and nitrogen by $8-10 \%$. Promising for further research is the study of the influence of biomass ash on the yield of volatile substances of the blend, as well as the study of slag characteristics of the ash blend. The possibility of further complete replacement of coal on the boiler.

Threats. To implement this technology, it is necessary to develop a mechanism for calculating the electricity generated at the «green tariff» in the case of co-combustion of biomass with coal. On the territory of the power plant, it will be necessary to organize a system for unloading, storage, transportation, grinding and feeding biomass to the burners. Biomass storage systems must be equipped with temperature control and fire extinguishing systems.

\section{Conclusions}

1. Having estimated the world experience of co-combustion of coal and biomass on flare boilers, it is possible to conclude that the production of this technology reduces emissions of harmful substances. And accordingly, the fee for them is $10-50 \%$, depending on the proportion of biomass in the blend. The most effective in terms of minimizing capital investment is direct co-combustion. In Ukraine, there is a wide resource base of biomass ( $23 \%$ of the country's primary energy consumption), which allows for the operation of part of the boilers of large power plants.

2. As a result of experimental studies, it is found that the addition of various types of biomass to lean and bituminous coals leads to an increase in the temperature in the core of the torch of $100-200{ }^{\circ} \mathrm{C}$. As well as to stabilize the combustion of the torch, its displacement towards the burner device, which in turn indicates an improvement in the ignition conditions of coal.

3. The obtained dependences of the burnout degree of a blend of various types of biomass with bituminous coal on the ratio of two fuels demonstrate an improvement in the degree of burnout of the blend with an increase in the proportion of biomass. The dependence is extreme when adding 7-14 \% of biomass for heat.

4. It is shown that an increase in the formation of thermal nitrogen oxides as a result of a local temperature increase is compensated by a decrease in the yield of fuel nitrogen oxides, which suggests a decrease in the total concentration of nitrogen oxides in the exhaust gases of the boiler.

\section{References}

1. Nechaieva, T. P. (2017). Assessment of the critical scenarios of coal supply for the Ukrainian power industry. The Problems of General Energy, 1 (48), 24-32. doi: http://doi.org/10.15407/ pge2017.01.024

2. Cherniavskyi, M. V., Volchyn, I. A., Provalov, O. Yu., Miroshnychenko, Ye. S., Roskolupa, A. I., Moiseienko, O. V. (2018). Rozrobka tekhnolohichnykh rishen dlia perevedennia antratsytovykh ta hazomazutnykh kotliv TETs na spaliuvannia hazovoho vuhillia. Vuhilna teploenerhetyka: shliakhy rekonstruktsii ta rozoytku. Kyiv, 189-194.

3. Cherniavskyi, M. V., Provalov, O. Yu. (2019). Naukovi osnovy ta tekhnichni rishennia dlia perevedennia Slovianskoi TES na hazove vuhillia. Vuhilna teploenerhetyka: shliakhy rekonstruktsii ta rozoytku. Kyiv, 106-110.

4. Verma, M., Loha, C., Sinha, A. N., Chatterjee, P. K. (2017). Drying of biomass for utilising in co-firing with coal and its impact on environment - A review. Renewable and Sustainable Energy Reviewos, 71, 732-741. doi: http://doi.org/10.1016/ j.rser.2016.12.101

5. Statistics: $\mathrm{CO}_{2}$ Emissions from Fuel Combustion 2018 Highlights (2018). International Energy Agency. Available at: https:// webstore.iea.org/co2-emissions-from-fuel-combustion-2018-highlights (Last accessed: 08.10.2019)

6. List of co-firing projects. Available at: https://demoplants21 bioenergy2020.eu/projects/displaymap/EGpJO2 (Last accessed: 10.10.2019)

7. Baxter, L. (2005). Biomass-coal co-combustion: opportunity for affordable renewable energy. Fuel, 84 (10), 1295-1302. doi: http://doi.org/10.1016/j.fuel.2004.09.023 
8. Demirbaş, A. (2003). Fuelwood Characteristics of Six Indigenous Wood Species from the Eastern Black Sea Region. Energy Sources, 25 (4), 309-316. doi: http://doi.org/10.1080/00908310390142343

9. Colechin, M., Malmgren, A. (2005). Best Practice Brochure: CoFiring of biomass (Main Report). Report No: Coal R 287 DTI/ Pub URN 05/1160, 91

10. Tillman, D. (2000). Biomass cofiring: the technology, the experience, the combustion consequences. Biomass and Bioenergy, 19 (6), 365-384. doi: http://doi.org/10.1016/s0961-9534(00)00049-0

11. Macierska, A., Veringa, H., Sanders, I., Peteves S. D. (2006) Co-firing of Biomass with coal: constrains and role of biomass pre-treatment. DG IRC EU Institute of Energy, (EUR $22461 \mathrm{EN})$ (LD-NA-22461-EN-C), 113.

12. Kiel, J. H. A. (2008). Biomass co-firing in high percentages opportunities in conventional and advanced coal-fired plants. IEA TASK32, Workshop Geertruidenberg, ECN-L-08, 42. Available at: https://publicaties.ecn.nl/PdfFetch.aspx?nr=ECN-L--08-080

13. Fossil Fuel Power Generation State-of-the art Report prepared by Power Clean $R$ (2004). D\&D Thematic Network 30th July 2004, Contract No. ENK5-CT-2002-20625, 84

14. Roni, M. S., Chowdhury, S., Mamun, S., Marufuzzaman, M., Lein, W., Johnson, S. (2017). Biomass co-firing technology with policies, challenges, and opportunities: A global review. Renewable and Sustainable Energy Revieros, 78, 1089-1101. doi: http://doi.org/10.1016/j.rser.2017.05.023

15. Bescennii, I. V., Schudlo, T. S., Dunaevskaia, N. I., Topal, A. I (2013). Issledovanie osobennostei goreniia smesei koksov uglei razlichnoi stepeni metamorfizma i koksov biomassy. Teploenergetika, 12, 4-8. doi: http://doi.org/10.1134/s0040363613120035

16. Cherniavskii, N. V., Dunaevskaia, N. I. (1991). Dinamika konversii malometamorfizirovannykh uglei pri gazifikacii v potoke. Problemy gazifikacii uglei. Krasnoiarsk: KATEKNIIenergetiki, 76-83.
17. Golyba, A. N., Zaruba, V. K., Kadochnikov, V. N., Oks, T. A (1995). Ob ustanovke vynosnykh kamer sgoraniia dlia nizkosortnogo uglia (kombastorov) firmy TRW (SSHA) pri rekonstrukci bloka 200 MVt Zmievskoi GRES. Energetika i elektrifikaciia, 3, 15-17.

18. Maistrenko, A. Iu., Cherniavskii, N. V., Iackevich, S. V. et. al. (1995). Ocenka uslovii stabilnogo goreniia vysokozolnogo ASH v fakelnykh kotloagregatakh s zhidkim shlakoudaleniem. Energetika i elektrifikaciia, 1, 14-17.

Beztsennyi Ihor, PhD, Senior Researcher, Coal Energy Technology Institute of National Academy of Sciences of Ukraine, Kyiv, Ukraine, e-mail: coalenergy@i.ua, ORCID: http://orcid.org/00000001-6536-5121

Bondzyk Dmytro, PhD, Senior Researcher, Coal Energy Technology Institute of National Academy of Sciences of Ukraine, Kyiv, Ukraine, bondzyk.dmytro@gmail.com, ORCID: http://orcid.org/00000003-3123-1971

Dunayevska Nataliya, Doctor of Technical Sciences, Senior Researcher, Director, Coal Energy Technology Institute of National Academy of Sciences of Ukraine, Kyiv, Ukraine,e-mail: dunayevskani@ukr.net, ORCID: http://orcid.org/0000-0003-3271-8204

Nekhamin Mark, PhD, Senior Researcher, Coal Energy Technology Institute of National Academy of Sciences of Ukraine, Kyiv, Ukraine, e-mail:nmark@i.ua, ORCID:http://orcid.org/0000-0003-3679-321X 